\title{
INFORMATION NEEDS OF WILDLIFE HUNTERS IN KWARA STATE: IMPLICATION FOR EXTENSION SERVICE DELIVERY IN NIGERIA
}

\author{
Lawal Lateef ADEFALU* \\ University of Ilorin, Faculty of Agriculture, Department of Agricultural Extension and Rural Development, \\ PMB 1515, Ilorin, Kwara State, Nigeria, email: adefalu.11@unilorin.edu.ng

\section{Oluwafemi Peter OLABANJI} \\ University of Ilorin, Faculty of Agriculture, Department of Agricultural Extension and Rural Development, \\ PMB 1515, Ilorin, Kwara State, Nigeria, email: folabanji21@yahoo.com \\ Habeeb Ifedolapo BHADMUS \\ University of Ilorin, Faculty of Agriculture, Department of Agricultural Extension and Rural Development, \\ PMB 1515, Ilorin, Kwara State, Nigeria, email: habeeb@touchandpay.me

\section{Sikiru IBRAHIM-OLESIN*} \\ Alex Ekwueme Federal University, Faculty of Agriculture, Department of Agriculture, \\ PMB 1010, Abakaliki, Ebonyi State, Nigeria, email: sikiruib@gmail.com

\section{Oyedola Waheed KAREEM} \\ University of Ilorin, Faculty of Agriculture, Department of Agricultural Extension and Rural Development, \\ PMB 1515, Ilorin, Kwara State, Nigeria, email: kareem.ow@ unilorin.edu.ng
}

Citation: Adefalu, L.L., Olabanji, O.P., Bhadmus, H.I., Ibrahim-Olesin, S., \& Kareem, O.W. (2021). INFORMATION NEEDS OF WILDLIFE HUNTERS IN KWARA STATE: IMPLICATION FOR EXTENSION SERVICE DELIVERY IN NIGERIA. Analele Universitătii din Oradea, Seria Geografie, 31(2), 153-163. https://doi.org/10.30892/auog.312106-873

\begin{abstract}
Access to accurate, timely and reliable information has crucial roles in production efficiency of wildlife hunters. An understanding of information needs could propel actors in the agricultural information business to provide information that will meet the needs. To this end, the present study investigated the information needs of wildlife hunters in Kwara State, Nigeria. A three-stage sampling technique was used to select 120 respondents for the study. Primary data collected with the use of interview schedule were analysed using descriptive and inferential statistical tools. The result revealed that hunters' group $(\mathrm{M}=2.48)$ and consultation with older/experienced hunters $(\mathrm{M}=2.02)$ were the prominent channels of information accessible to the hunters. Information on market situation $(\mathrm{M}=2.16)$, games search techniques and ethics $(\mathrm{M}=2.07)$ and hunting locations $(\mathrm{M}=1.98)$ were the major areas of information needs of the hunters. Also, lack of awareness of extension information source $(M=1.96)$, inaccessibility of extension workers $(M=1.86)$ and trust of the information source $(M=1.79)$ were the major identified obstacles to accessing information from extension channels. The study further showed that age of the hunters, level of education and years of experience have a significant relationship with their information needs at $\mathrm{p}<0.05$. The study concluded that the hunters have ample information needs and recommends that an arm of extension service operation should be
\end{abstract}

\footnotetext{
${ }^{*}$ Corresponding Author
} 
devoted to wildlife with the mandate of hunters' education on vital areas of wildlife management for improved livelihood.

Key words: bushmeat, hunting location, market situation, information source

$$
* \quad * \quad * \quad * \quad * \quad *
$$

\section{INTRODUCTION}

In Nigeria and other developing countries, wildlife hunting is a popular activity in rural areas. Aside crop farming and animal husbandry, hunting is a major source of livelihood for most of the people in these areas (Adefalu, Aderinoye-Abdulwahab, Akangbe, Ogunlade, \& Matanmi, 2013). Hunting is an activity where animals in the wild are been killed for food or market purposes. Wildlife hunting is presumed to have dated back to the time of human evolution (Ljung, Riley, Heberlein, \& Ericsson, 2012). Despite the lack of precise estimates on bush meat consumption and total production, bush meat still remains a highly valued and well-preferred protein of animal source in the diets of both in the rural and urban populace in many parts of Africa (FAO, 1997).

Based on the purpose for hunting, hunters are usually categorized as market hunters, subsistence hunters, and sport hunters. Market hunters provided meat for buyers. Subsistence hunters hunt primarily to feed their families. While sport or trophy hunters hunt as a form of recreation (Adefalu, Aderinoye-Abdulwahab, Akangbe, Ogunlade, \& Matanmi, 2013). In Nigeria, these hunters have a common attitude that wildlife is limitless. Hunting of wild animals on this scale threatens wildlife conservation, increases risk of zoonotic disease transmission and gradually declines bushmeat trade due to uncontrolled hunting (Keatts, et al., 2021). Deforestation which sometimes results from bush burning as a strategy for the hunters to capture their games has also been identified for its effects on the microclimate of Kwara State (Agaja, 2019; Karesh \& Noble, 2009). With the growing campaign for wildlife conservation around the world and to avert the unsustainable hunting practices in Nigeria, hunters must be adequately furnished with information that will guide them and improve their efficiency while observing ethics of hunting operations. Effective access to relevant information by wildlife hunters is essential for regulating their activities and bringing about social and economic change.

Information has been described as a very crucial factor in development owing to the fact that, it serves as a vital tool of communication between stakeholders. Additionally, it is a medium for trends assessment and also aid in sharpening decision in an enterprise or a social setup (Whitfield, 2017). Knowledge emerging from information are essential in order to respond to the opportunities and challenges of social, economic and technological changes including those that help to improve productivity, food security and rural livelihood (Olabanji \& Ogunlade, 2020). Dutta (Dutta, 2009) acknowledged that information plays an important role in the lives of the wildlife hunters as it helps them become more knowledgeable with best hunting practices for improved productivity, better welfare and ethics consciousness. Information is a catalyst for solving a problem and a very important tool for economic development (Sobalaje \& Ogunmodede, 2015; Ogunmodede \& Akangbe, 2013). The extension service delivery system is the most important information service for the public that has the widest range of responsibilities for rural and agricultural development. An extension worker serves as conduit pipe between researchers and farmers through the transmission of information on improved technique that will enable increased productivity even in hunting expedition.

Ozoma (Ozoma, 1998) noted that wildlife hunters need information on hunting activities, ethics, weather conditions, treatment and control of diseases, type of animal to kill, hunting techniques, safety precautions, market situation among others. The need for increased ethical understanding and attitude in hunters has been recognized in a growing climate of polarized thinking about hunting. With increased knowledge, a hunter will be able to articulate why he or she hunts, and to hold or to work toward a consistent ethic (Chapman, 2009). Consequently, the inadequate 
attention given to hunting services in Nigeria by extension organisations, understanding the information needs of hunters could form a base for the establishment of hunters' education in the service sector. Based on this background, this study sought to investigate the extension needs of wildlife hunters in Kwara state, Nigeria with the objectives of determining the information needs of hunters in the study area, assessing the current information sources available to the hunters and examining the obstacles to the hunters' information access. The hypothesis tested was whether or not there is a significant relationship between some selected socio-economic characteristics of the respondents and their information needs.

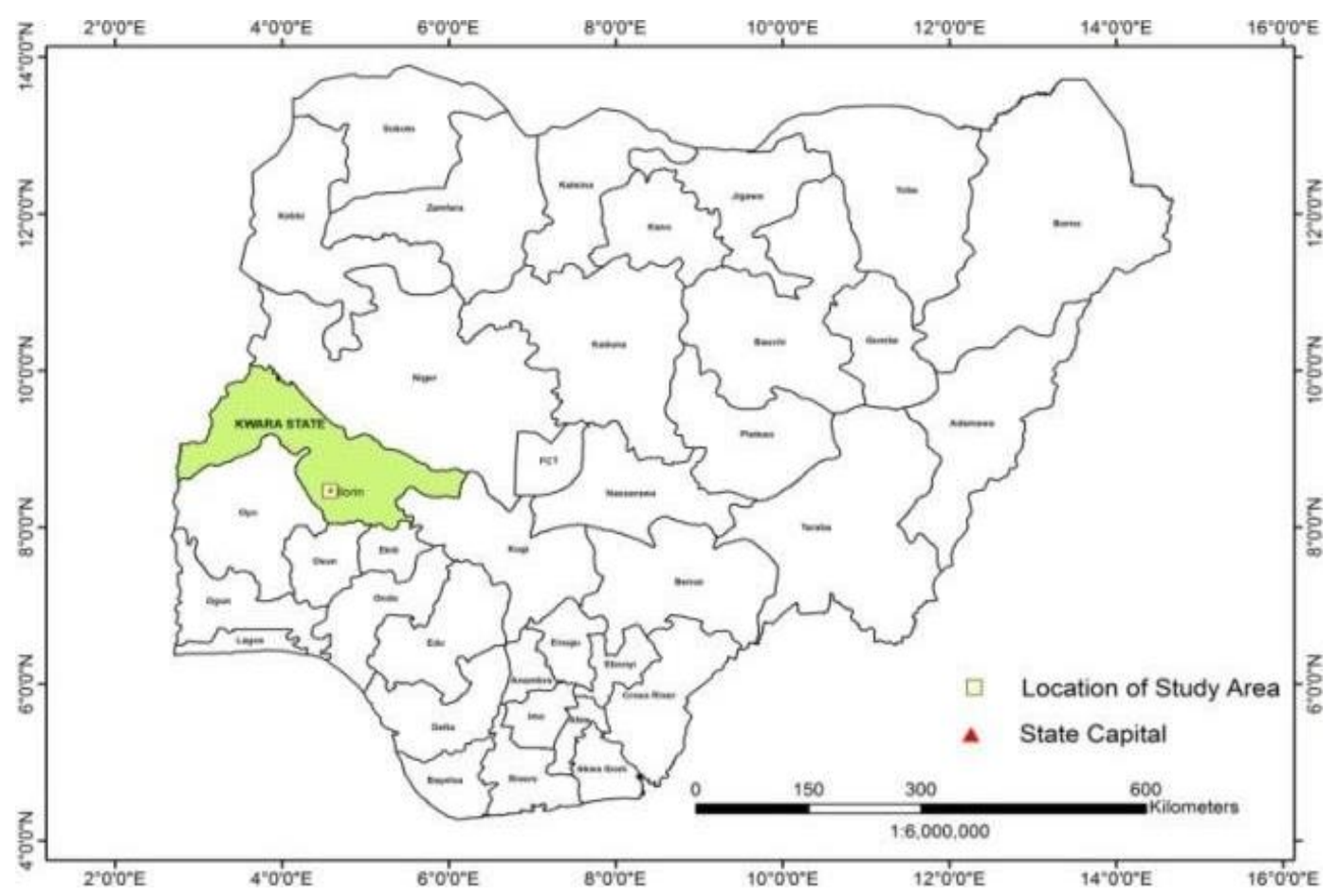

Figure 1. Map of Nigeria showing Kwara State as the study area and other States of Nigeria Source: Researchgate.net

\section{METHODOLOGY}

The study was carried out in Kwara State, Nigeria. Kwara State was created in 1967, and it covers eight percent of the total land area of Nigeria. The state extends from latitude $7^{\circ} 45^{\circ} \mathrm{N}$ in its southern end, latitude $2^{\circ} 45^{\prime} \mathrm{E}$ to the west and longitude $6^{\circ} 40^{\prime} \mathrm{E}$ to south east as shown in figure 1 . It has a total population of 3,192,893 (National Bureau of Statistics, 2017) with a population density of 66 people $/ \mathrm{km}^{2}$. The State is typically agrarian. Eighty percent of the population resides in the rural areas and $90 \%$ of this rural population are farmers (Yusuf, Tiamiyu, \& Aliu, 2016). The state has a mean annual temperature ranging between $30-35^{\circ} \mathrm{C}$ and a relative humidity of $60 \%$ on the average. The area is located within the Guinea Savanna and a tropical hinterland (Ifabiyi \& Oluwashina, 2011) . The climate, vegetation pattern and forest densities make the state a major hunting area. The state has 16 Local Government Areas (LGA) classified by Agricultural Development project (ADP) into four Agricultural zones, 23 blocks and 184 cells in consonance with ecological characteristics and cultural practices. The zones comprise Zone A (with headquarters at Kaiama), Zone B (with headquarters at Lafiaji), Zone C (with headquarters at Ilorin East) and Zone D (with headquarters at Igbaja). The population for the study comprises of all wildlife hunters in Kwara State, Nigeria. Three stage sampling technique was adopted for the study. The first stage 
was a purposive selection of Zone $\mathrm{C}$ and $\mathrm{D}$ of the ADP zones based on the population of wildlife hunters in that area and the abundance of forest land where hunting activities are carried out. In the second stage, 4 Local Government Areas were randomly selected from each of the selected zones. Lastly, a proportionate sampling technique was used to select the respondents from a list of hunters in each LGAs. Information on the number wildlife hunters in each LGAs was obtained through the assistance of the hunters' association in the area. In the end, a total of 120 respondents were used for the study. Data were collected through personal interview schedule for unlearned respondents and questionnaire for the learned ones. The data elicited were on the information needs of hunters, their current information sources and the obstacles they face to access Information. Descriptive statistics such as precisions counts and percentage were used to describe the data collected, while Pearson product moment correlation was used to test the formulated hypothesis. The information needs of the hunters was assessed using a four-point Likert type scale of Very Highly Required (3), Highly Required (2), Required (1) and Not Required (0) with a cut-off point of 1.5 The accessible information sources were measured using a four-point likert scale of regularly (3), sometimes (2), rarely (1) and Never (0). Also, obstacles faced in accessing information were determined using fourpoint Likert scale of very severe (3), moderately severe (2), severe (1) and not severe (0).

\section{RESULT AND DISCUSSION}

\section{Socioeconomic Characteristics of the Respondents}

The data of the figure 2 shows that the average age of the respondent was 39.7 years. According to Oladeji and Thomas (Oladeji \& Thomas, 2010), populations within the age group of 31-40 years are productive and energetic enough to take part in toilsome activities as hunting. Considering the Nigerian Youth Policy (Nigeria Youth Policy, 2019) which puts youth to person with age range between 18 and 29, the average age of the respondents therefore shows that they are no longer youths. Adefalu et al. (Adefalu, Aderinoye-Abdulwahab, Akangbe, Ogunlade, \& Matanmi, 2013) had identified that the average age of hunters in Kwara State was 27.8 years. With this current finding that the average age of hunters is 39.7 years, it is enough to say that youths are no longer actively involved in hunting in the state. This finding also confirms Layade et al. (Layade, Layade, Kehinde, Alaye, \& Jayeoba, 2021), which posited that the age range of hunters in Ido, Oyo State, Nigeria is between 31 and 50 years. Also, available literatures show that only people below the age of 12 are not allowed to hunt in states like, California, Colorado, and Gorgia among others, while states like Florida, Illinois, Hawai put the minimum hunting age to be 16 (Gothunts, 2021). The prevalence of people of about 40 years in hunting activities may be for financial gains owing to the current unemployment situation in the country as identified by Layade et al (Layade, Layade, Kehinde, Alaye, \& Jayeoba, 2021).

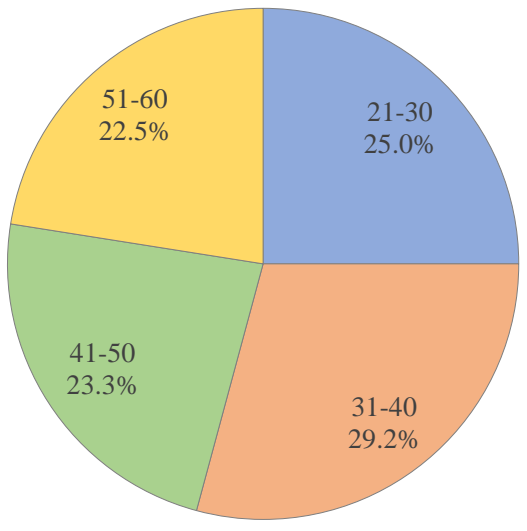

Figure 2. Age of the respondents Data source: Field Survey, 2019 
The result further revealed that all $(100 \%)$ of the respondents were males. This is very much in line with the findings of Layade et al. (Layade, Layade, Kehinde, Alaye, \& Jayeoba, 2021) where $96 \%$ of hunters in Ido, Oyo State, Nigeria were men. This is however appropriate for the study because men are known with the responsibilities of taking care of their families and will take on any task to deliver this responsibility even when it is onerous, though, women too according to some studies were highlighted as being partnering with men in hunting (Singh, 2001). Additionally, the result shows that the majority $(65.0 \%)$ of the hunters were married while $17.5 \%, 11.7 \%$, and $5.8 \%$ were single, separated/divorced and widowed respectively. By this it is obvious that most of them have responsibilities to discharge in their homes (Matanmi, et al., 2015). The majority of respondents being married also confirm Layade et al (Layade, Layade, Kehinde, Alaye, \& Jayeoba, 2021), where $84 \%$ of the hunters assessed in Oyo State, Nigeria was married.

Figure 3 shows that about $26.7 \%$ of the respondents have no formal education while a notable proportion (73.3\%) was formally educated. $20.8 \%$ had secondary school education, this is not far from the findings of Layade et al. (2021), where only $13 \%$ of the hunters identified had no formal education. $35.0 \%$ had primary education, and $17.5 \%$ had tertiary education). This implies that the hunters have the ability to acquire knowledge when information is made available.

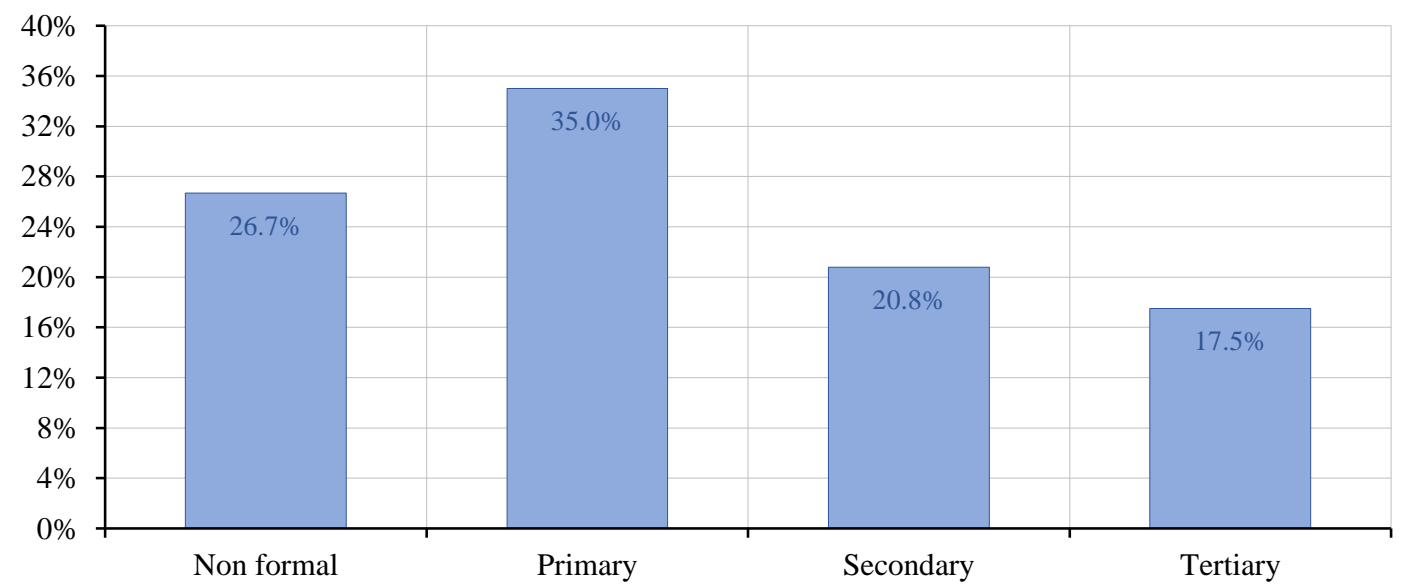

Figure 3. Respondents' level of education Data source: Field survey 2019

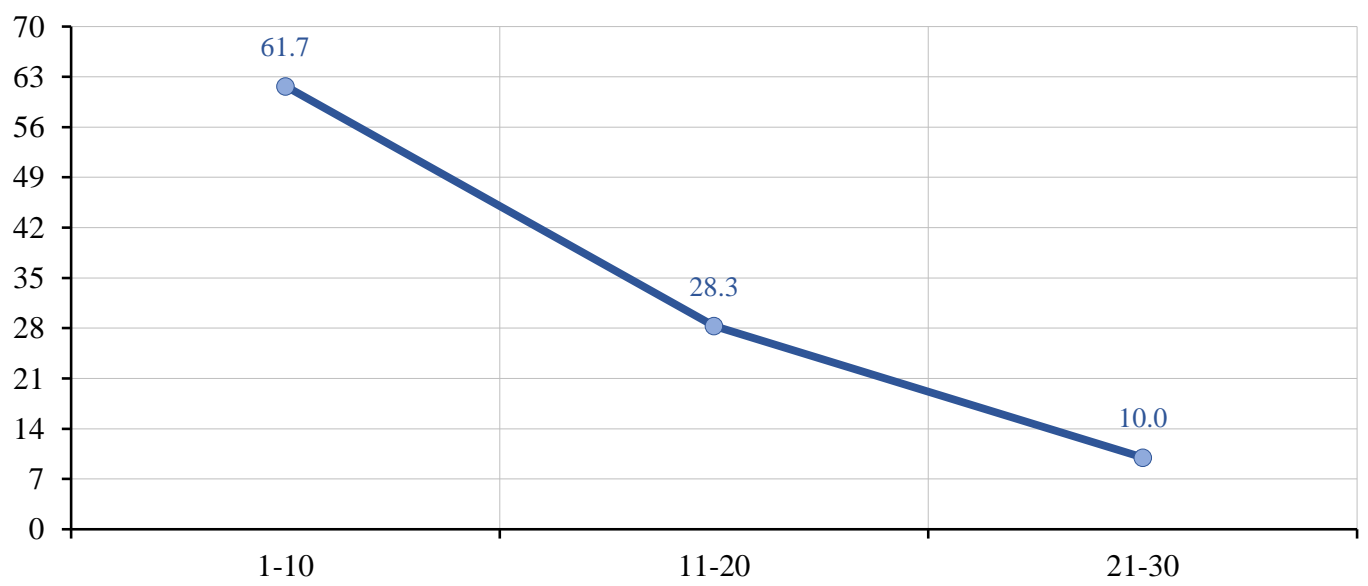

Figure 4. Respondents'hunting experience Data source: Field Survey, 2019 
From figure 4, the mean of the hunters' years of experience was 10.3years, which shows that they are highly experienced in the hunting activities. This may also due to the profitability of the enterprise which ensures it continuance for more than 10 years. Averagely, each of them has a household size of 6 persons. This shows that they are responsible. Being responsible to the family will open more ways to seek means of sustainable livelihood.

\section{Accessible Sources of Information}

Table 1 shows a list of information sources on hunting activities and how accessible they have been to the respondents. Hunter' group ranked first as the most accessible source of information with a weighted mean score of 2.48. This implied that hunters get information on where to hunt from their fellow hunters. In Kwara State, each village or rural community has stipulated time when their bush will be hunted, and the information about such is mostly shared from peer to peer as revealed by this study. In some occasions, a calendar of dates for hunting different villages or rural community will be announced in gatherings that precede any hunting activity. Apart from the information gotten from the hunter's group, information is also gotten by consulting older/experienced hunters (2.02). Such kind of information however has to do with issues that bother hunting activities like the mode of engagement in an event of dangerous animals, mentoring on the preparation for a hunt, markets for the game, among others (Layade, Layade, Kehinde, Alaye, \& Jayeoba, 2021). Radio takes the $3^{\text {rd }}$ position in the ranking of sources of information of the hunters on hunting activities with mean 1.95. Dedicated Radio program titled Akinkanju Ode, meaning "the brave hunter" is being aired on a dedicated day and time of the week. Through this program, hunters who were already aware of this program use the opportunity to listen to announcements, shared experience and skills that may be useful in their hunting activities. Other relatively accessible information sources include television (1.90), which ranked $4^{\text {th }}$; family and friends (1.83) which ranked $5^{\text {th }}$, internet (1.68), print media (1.59), and extension agents $(0.80)$ which ranked $6^{\text {th }}, 7^{\text {th }}$ and $8^{\text {th }}$ respectively. Rural people will always explore various options to get the information they need per time, and more information will be gotten through the means that is easily accessible to them (Demiryurek, 2010).

Table 1. Distribution of respondents based on level of access to various information sources Data source: Field survey, 2019

\begin{tabular}{|l|c|c|}
\hline Accessible Sources & Mean Score & Rank \\
\hline Consulting elders/experienced hunters & 2.02 & 2nd \\
\hline Hunters' Group & 2.48 & 1 st \\
\hline Family and Friends & 1.83 & 5th \\
\hline Radio & 1.95 & 3rd \\
\hline Television & 1.90 & 4th \\
\hline Internet & 1.68 & 6th \\
\hline Printed materials (Newspapers, articles, Journals etc) & 1.59 & 7 th \\
\hline Extension agents & 0.80 & 8th \\
\hline
\end{tabular}

\section{Perceived Information Needs by the Respondents}

It is evident from figure 5 that the respondents required all the listed information areas to improve their expedition experience as hunters. Based on needs, information on market situation was regarded as the most required $(\mathrm{M}=2.16)$. The trading of the products of wildlife represents a very important income source the poor (McNamara, et al., 2016), that could be the reason why the information on the situation of wildlife products market ranked $1^{\text {st }}$. Situation of the market determines the supply of wildlife products, as many hunters will be pushed to more hunting activities having realized the market demands for the products. Fortunately, wildlife products provide a source of livelihoods for the hunters, the traders and the sellers of the products, while it is also an important source of protein both rural and urban consumers of the products. The Games search techniques and ethics ranked $2^{\text {nd }}(M=2.07)$. This could be due to the fact that anyone can not just go into hunting 
without prior mentorship. Friant et et al. (Friant, Paige, \& Goldberg, 2015) has identified that hunters are predisposed to different types of risks during hunting activities, among which is the risk of contacting zoonotic disease, and encounter with dangerous animals. This has enhanced the need for the ethics and techniques in search of games. Hunters always seek means to be safe, as coming back home safely is more important than getting the games. Information on hunting location ranked $3^{\text {rd }}$ with mean 1.98. Getting the knowledge of the locations to hunt will bring about necessary preparations that may be needed. Hunters always seek to know where hunting activities will take place so as not to lose the chance of the hunting experience. Information on Safety precaution ranked $4^{\text {th }}$ with mean 1.89 , this also is in line with games search techniques and ethics. Awareness of diseases from games and the possibility of brutal attacks by some dangerous animals necessitate the need for information on safety precautions (Friant, Paige, \& Goldberg, 2015). Other areas where information are needed by the hunters with less severity were; laws guiding hunting $(\mathrm{M}=1.83)$, weather situation $(\mathrm{M}=1.80)$, processing of captured games $(\mathrm{M}=1.68)$, and types of animal to hunt (1.67), and they ranked $5^{\text {th }}, 6^{\text {th }}, 7^{\text {th }}$ and $8^{\text {th }}$ respectively.

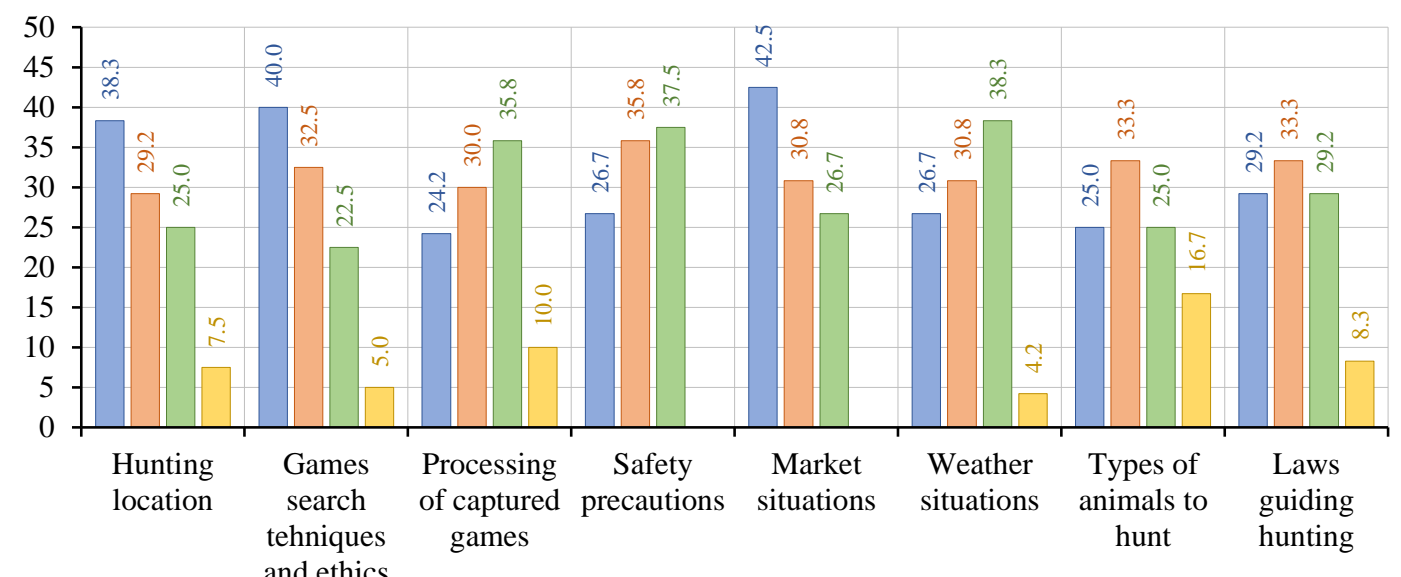

Figure 5. Perceived information need by the respondents Data source: Field Survey, 2019

\section{Obstacles to accessing Extension Information Source}

Figure 6 shows that the most severe obstacle to accessing information from extension source was lack of awareness of the information source $(M=1.96)$. The importance of the delivery of extension information in a bid to help smallholder farmers to overcome agricultural production challenges or provide better ways of increasing production has been well identified (Antwi-Agyei \& Stringer, 2021). Unfortunately, hunters in Kwara State were still not aware of any extension services aimed at helping the hunters. In addition, there is dearth of information on extension information to the hunters, and this may contribute to the lack of its awareness. This was followed by inaccessibility of extension workers by the hunters $(\mathrm{M}=1.86)$. Maulu et al (Maulu, Hasimuna, Mutale, Mphande, \& Siankwilimba, 2021) has identified that effective extension programs in the rural areas is crucial in solving many rural problems, extension activities have been greatly affected by myriads of factors that made it inaccessible to the farmers and rural people (Akinnagbe, Ezeuzo, \& Onwubuya, 2017). Trust of the information source ranked 3rd, with mean 1.79. This is because, the majority of the hunters were addicted to indigenous knowledge, and they put their trust more on peer to peer information or information from more experienced hunter as revealed above. Other perceived obstacles included doubt on availability of required information $(M=1.75)$, and distance from home to extension office $(\mathrm{M}=1.67)$. However, Preference for other information sources $(\mathrm{M}=$ $1.33)$, language barrier $(M=1.23)$ and cultural belief $(M=1.16)$ were regarded as not severe 
obstacles to accessing information from extension source. Issa (Issa, 2010) mentioned that extension service delivery in Nigeria has not met the desired coverage own to the challenges facing it.

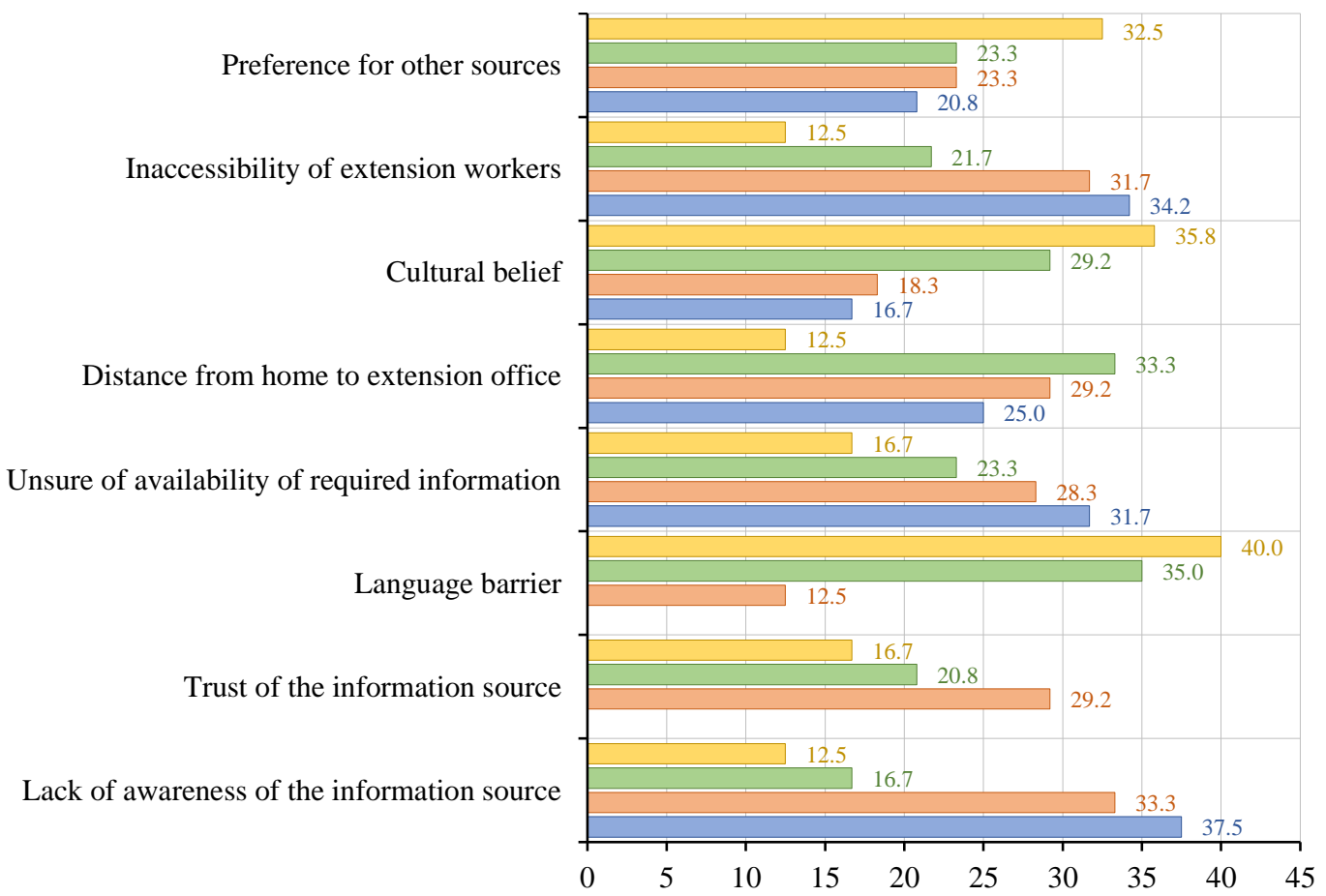

Figure 6. Obstacle to accessing Extension information by the respondents

Data source: Field Survey, 2019

\section{Test of Hypothesis}

Table 2 revealed that at 5 percent degree of freedom, age $(p=0.033)$, level of education $(0.010)$ and years of hunting experience $(p=0.037)$ shows a significant relationship with information needs of the hunters. This also confirmed Friant et al (2015). However, marital status $(p=0.065)$ and household size $(p=0.063)$ were not significant. The negative significance of the age implies that the younger the hunters the more inquisitive they are to acquire new knowledge. Also, the more educated an individual is, the more the chances of wanting more knowledge. In addition, lesser years of experience could prompt enquiries for more knowledge. Adeogun (Adeogun, 2008), had opined that, the younger the farmers the more likely the willingness to spend more time obtaining information on improved technologies compared to the old farmers. Educated farmers can easily access information from various sources, and can be able to generate knowledge out of those sources (Estruk \& Oren, 2014). Longer years of experience implied accumulation of knowledge and skill which contributes to utilization of technologies (Namwata, Lwelamira, \& Mzirai, 2010).

Table 2. Pearson Product Moment Correlation results of the relationship between Hunters' Socioeconomic Characteristics and their information needs Data source: Source: Computed from Field data, 2019

\begin{tabular}{|l|c|c|c|}
\hline Variable & r-value & p-value & Remarks \\
\hline Age & -0.194 & 0.033 & Significant \\
\hline Marital status & 0.236 & 0.065 & Not significant \\
\hline Level of Education & -0.357 & 0,010 & Significant \\
\hline Household size & 0.246 & 0.063 & Not significant \\
\hline Hunting experience & -0.191 & 0.037 & Significant \\
\hline
\end{tabular}




\section{CONCLUSION AND RECOMMENDATION}

With increasing human populations, increasing commercialisation of bush meat and increasing access to the forest, games hunting has become the most significant immediate threat to wildlife in most African countries. Unsustainable levels of hunting threaten not only the survival of hunted species and their ecosystems, but also the livelihoods and food security of the rural poor who are dependent on wildlife as a protein resource. For this reason, educating hunters with requisite information is a significant way forward. Sustainable hunting promises a good source of income to the farmers, in a way that will not destroy the conservation of wildlife. Arising from the foregoing, hunters have needs for information especially in the areas of market situation, games search techniques and ethics as well as hunting locations for wildlife. The quest for information on market situations of products of wildlife hunting due to the growing markets and poverty situation of the country should not be an avenue to uncontrolled hunting which will be a great threat to the ecosystems of the wildlife and food security, since the majority of the majority of rural poor depend on wildlife as a source of protein. Rather, the growing market of wildlife products should be welcomed by proper information and required guide on the need to preserve the forests through sustainable hunting. Also, with the hunters need for games search techniques and ethics, proper guide should be given to the hunters as the hunters in many occasions resort to bush burning to get their games. This in some occasions have resulted to uncontrolled wild fire which has wrecked havoc to many farms, destroyed ecosystems in many countries, and has even led to the loss of lives. With their need for information on hunting locations however, anti-poaching laws should be made known to the hunters in order to avoid hunting in restricted areas. Furthermore, several ways through which hunters always employ to evade arrest and persecution in events of poaching should be identified and made known to the hunters so to enable more consciousness. Also, hunters' lack of awareness of extension information source and inaccessibility of extension workers were identified as the most severe obstacles to accessing extension information. Though the hunters prefer getting information from their group members and more experienced hunters, this may be due to their lack of awareness of extension information on wildlife and inaccessibility of the available ones. Based on these results, agricultural development programme should dedicate an extension department to service wildlife hunters. This will however be very instrumental in addressing several issues that has roots in lack of awareness of laws guiding hunting, ethics in search of games, safety of the hunters, information on hunting locations, and the need for sustainable hunting

\section{IMPLICATION FOR EXTENSION}

To transform wildlife hunting in Nigeria, positioning extension as the driving wheel is essential. It is a well-known fact that agricultural extension is an important service for assisting the rural poor to enhance their livelihoods. Anticipated outcomes of agricultural extension service delivery in improving rural lives is yet to be attained. This is mainly due to the fact that public extension service, which is the only way in Nigeria, has not maximized the full potentials of rural areas. It has been noted that public extension service is geared towards crop and livestock production, paying almost no attention to wildlife hunting and management. In a growing climate of polarized thinking about hunting, especially with the increasing demands that hunters be ethical, developing an understanding of the role of hunters' education is vital. Hunting when unregulated may reduce wildlife populations below the environmental carrying capacity and change the behaviour of wildlife. When regulated wildlife could tremendously impact rural livelihood and add values to agricultural sector of the country. To this end, the agricultural extension experts, practitioners, and promoters could play significant roles. Agricultural extension workers, who are major promoter of the knowledge and technology transfer, should be well equipped with communication and demonstration skills to implement the task of hunters' education in most effective ways. Effectiveness, efficiency and quality of agricultural extension service provision are mainly a function of the competency of professionals in terms of the required knowledge, skills and attitudes. Technical and communication skills are paramount for promotion and dissemination of information 


\section{Aknowlegments}

The authors of this work are highly grateful to Hunters Association in Kwara State for their cooperation in reaching out to their members who were the sole respondents for this research.

\section{REFERENCES}

Adefalu, L., Aderinoye-Abdulwahab, S., Akangbe, J., Ogunlade, I., \& Matanmi, B. (2013). Local Hunting Strategies in Kwara State, Nigeria: Challenge for Wildlife Conservation Policy Enforcement. Albania Journal of Agricultural Science, 12(4), 627-632.

Adeogun, S. (2008). Adoption of cocoa rehabilitation techniques among cocoa farmers in selected states of Nigeria. An unpublished PhD Thesis in the Department of Agricultural Extension and Rural Development, University of Ibadan, Ibadan, Nigeria.

Agaja, T. (2019). Deforestation and Micro-Climate of Ilorin and Its Environs. Analele Universităţii Din Oradea, Seria Geografie, 29(2), 77-85. doi:https://doi.org/10.30892/auog.292108-806

Akinnagbe, O., Ezeuzo, O., \& Onwubuya, E. (2017). Challenges of extension workers in reaching rural women farmers in Enugu State Nigeria. Journal of Agricultural Extension, 21(3), 22-36. doi:https://doi.org/10.4314/jae.v21i3.3

Antwi-Agyei, P., \& Stringer, L. (2021). Improving the effectiveness of agricultural extension services in supporting farmers to adapt to climate change: Insights from northeastern Ghana. Climate Risk Management, 32. doi:https://doi.org/10.1016/j.crm.2021.100304

Chapman, S. (2009). The Importance of the Hunter Education Program to the Development of Ethical Literacy Among the Hunting Community. The Institute for Applied \& Professional Ethics Archives. Retrieved July 5, 2021, from https://www.ohio.edu/ethics/tag/hunting-community/

Demiryurek, K. (2010). Information system communication networks for agriculture and ruralpeople. Agricultural Economics-Czech, 56(50), 209-214.

Dutta, R. (2009). Information needs and information seeking behaviour in developing countries: a review of the research. The International Information and Library Review, 41(1), 44-51.

Estruk, O., \& Oren, M. (2014). Impact of household socio-economic factors on food security: Case of Adana, Turkey. Pakistan Journal of Nutrition, 13(1), 1-6.

FAO. (1997). Wild Life and Food Security in Africa. Retrieved from http://www.fao.org/3/w7540e/w7540e00.htm\#Contents

Friant, S., Paige, S., \& Goldberg, T. (2015). Drivers of Bushmeat Hunting and Perceptions of Zoonoses in Nigerian Hunting Communities. PLOS Neglected Tropical Diseases, 9(5).

Gothunts. (2021). Hunting Age Requirements for Each States. Retrieved from https://gothunts.com/huntingage-requirements/

Ifabiyi, I., \& Oluwashina, O. (2011). Rainfall Characteristics and Maize Yield in Kwara State, Nigeria. Indian Journal of Fundamental and Applied Life Sciences, 1(3), 60-65.

Issa, F. (2010). Overview of the challenges ofagricultural extension practice, researchand technology development and transfer. Journal of Sustainable Development, 7(1), 70-77.

Karesh, W., \& Noble, E. (2009). The Bushmeat Trade: Increased Opportunities for Transmission of Zoonotic Disease. Mount Sinai Journal of Medicine, 76, 429-434. doi:10.1002/msj.20139

Keatts, L., Robards, M., Olson, S., Hueffer, K., Insley, S., Joly, D., . . Walzer, C. (2021). Implications of Zoonoses From Hunting and Use of Wildlife in North American Arctic and Boreal Biomes: Pandemic Potential, Monitoring, and Mitigation. Frontiers in Public Health, 9. doi:https://doi.org/10.3389/fpubh.2021.627654

Layade, K., Layade, A., Kehinde, O., Alaye, S., \& Jayeoba, W. (2021). Assessment of Wildlife Hunting Activities in Ido Local Government Area, Oyo State Nigeria. Journal of Applied Sciences and Environmental Management, 25(3), 415-418. doi:https://doi.org/10.4314/jasem.v25i3.16

Ljung, P., Riley, S., Heberlein, T., \& Ericsson, G. (2012). Eat prey and love: Game-meat consumption and attitudes toward hunting. Wildlife Society Bulletin, 36, 669-675. doi:10.1002/wsb.208

Matanmi, B., Oladipo, F., Adefalu, L., Olabanji, O., Yusuf, S., \& Abdulkareem, T. (2015). Effect of the Use of Agrochemicals among Arable Farmers in Oyo State, Nigeria. Production Agriculture and Technology Journal, 11(2), 20-28. 
Maulu, S., Hasimuna, O., Mutale, B., Mphande, J., \& Siankwilimba, E. (2021). Enhancing the role of rural agricultural extension programs in poverty alleviation: A review. Cogent Food \& Agriculture, 7(1). doi:https://doi.org/10.1080/23311932.2021.1886663

McNamara, J., Rowcliffe, M., Cowlishaw, G., Alexander, J., Ntiamoa-Baidu, Y., Brenya, A., \& MilnerGulland, E. (2016). Characterising Wildlife Trade Market Supply-Demand Dynamics. PloS one, 11(9). doi:https://doi.org/10.1371/journal.pone.0162972

Namwata, B., Lwelamira, J., \& Mzirai, O. (2010). Adoption of improved agricultural technologies for Irish potatoes (Solanum tuberosum) among farmers in Mbeya Rural district, Tanzania: A case of IIungu ward. Journal of Animal and Plant Sciences, 8(1), 927-935.

National Bureau of Statistics. (2017). Demographic Statistics Bulletin. Federal Republic of Nigeria.

Nigeria Youth Policy. (2019). Enhancing Youth Development and Participation in the Context of Sustainable Development. Retrieved from https://ndlink.org/nigerias-national-youth-policy-2019-2023/

Ogunmodede, T., \& Akangbe, C. (2013). Effect of road safety information availabilityand utilization on commercial motorcycle accidents in Nigeria. International Journal of Library and Information Science, $5(3), 68-76$.

Olabanji, O., \& Ogunlade, I. (2020). Scale Development and Validation for Farmers' Knowledge Exchange: Implication for Agricultural Extension in Nigeria. Journal of Bangladesh Agricultural University, 18(4), 1029-1034. doi:https://doi.org/10.5455/JBAU.5987

Oladeji, J., \& Thomas, K. (2010). Social marketing approach as an alternative extension delivery for nutrition intervention among women in Osun State, Nigeria. International Journal of Applied Agricultural Research, 5(5), 657-667.

Ozoma, V. (1998). The nature of agricultural information needs of small scale farmers in Africa: The Nigerian experience. Nigeria Agricultural Journal, 29, 158-169. doi:10.4314/naj.v29i1.49310

Singh, K. (2001). Gender Roles in History: Women as Hunters. Gender, Technology and Development, 5(1), 113-124. doi:10.1080/09718524.2001.11909990

Sobalaje, A., \& Ogunmodede, T. (2015). Role of academic library in the National andEconomic Development of Nigeria. Greener Journal of Social Sciences, 5(2), 36-41.

Whitfield, S. (2017). More vital to our future than we realize?' Learning from Netting's thesis on smallholder farming, 25 years on. Outlook on Agriculture, 46(4), 258-264.

Yusuf, T., Tiamiyu, S., \& Aliu, R. (2016). Financial analysis of poultry production in Kwara State, Nigeria. African Journal of Agricultural Research, 11(8), 718-723.

Submitted:

July 12,2021
Revised:

November 24, 2021
Accepted and published online December 2, 2021 